\title{
Effects of some trace elements on urea hydrolysis in soils
}

\author{
M. A. Daif' and M. L. van Beusichem
}

Department of Soil Science and Plant Nutrition, Agricultural University, De Dreijen 3, NL 6703 BC Wageningen, the Netherlands

Accepted: 10 July 1981

Key-words: ammonia volatilization, heavy metals, nitrification, nitrogen fertilizer, urea hydrolysis, urease activity, urease production

\section{Summary}

The aim of this work was to evaluate iron, copper, and zinc ions as inhibitors to control urea hydrolysis, biosynthesis of urease, and ammonia evolution in some Spanish soils treated with urea.

The main results obtained in this investigation can be summarized as follows.

- These ions inhibited the urease activity by $7-20 \%$ when applied at $20 \mu \mathrm{g} \mathrm{g}^{-1}$ of soil.

- The inhibitory effect was most pronounced in light-textured soils. The cupric ion, in this respect, was the most effective one.

- These elements did not inhibit microbial production of urease in two soils tested, even when applied at $20 \mu \mathrm{g} \mathrm{g}^{-1}$ of soil.

- Compared with zinc and ferrous ions, the cupric ion markedly retarded urea hydrolysis and reduced the loss of urea- $\mathrm{N}$ as ammonia, in one soil tested.

\section{Introduction}

The rapidly increasing importance of urea as a nitrogen fertilizer in world agriculture has emphasized the need for research to find methods of reducing some of the problems encountered in its use as a fertilizer.

One approach to reduce the problems associated with the use of urea as a fertilizer is to find agents to retard its hydrolysis when applied to soils. Any compound proposed to inhibit urease activity in soils must be cheap, effective and safe to use. For effectiveness, the inhibitor must dissolve and move with the fertilizer urea when its granules are applied to the soil. This approach has received considerable attention, and many compounds have been tested and patented as inhibitors of urea hydrolysis in soils (Anderson, 1962, 1969; Besekau et al., 1974;

1 Present address: Department of Soil Science, Faculty of Agriculture, Cairo University, Giza, Egypt. 
Bremner \& Douglas, 1971a; Geissler et al., 1970; Hyson, 1963; Peterson \& Walter, 1970; Sor, 1968, 1969; Sor et al., 1968, 1971; Tomlinson, 1967). Most of these inhibitors are inorganic or organic compounds, previously shown to be potent inhibitors of urease activity in vitro.

Peterson \& Walter (1970), however, claim that urea hydrolysis in soils can also be retarded through addition of compounds that function as anti-metabolites towards urease-producing micro-organisms. In these cases the inhibitory effect on urea hydrolysis in soils is based on controlling the production of (extracellular) urease by soil micro-organisms.

Daif \& Badr El-Din (1979) studied the effect of some heavy metals on urease activity in vitro using pure jack bean urease. They reported that use of iron, copper, and zinc to delay urea hydrolysis is possible. Consequently, the purpose of the work reported here was to evaluate iron, copper, and zinc as inhibitors to control urea hydrolysis, microbial production of urease, and ammonia evolution in soils treated with urea.

\section{Materials and methods}

The soils used were surface $(0-30 \mathrm{~cm})$ samples, taken in the Calamonte area near Mérida in the province of Badajoz, Spain. They were selected to obtain a wide range in properties (Table 1). Before use, each soil sample was air-dried and crushed to pass a $2-\mathrm{mm}$ screen. In the analyses reported in Table 1, particle-size distribution was determined by pipette analysis (silt and clay) after destruction of organic matter by hydrogen peroxide and dispersion with sodium pyrophosphate, sand was determined by sieving, calcium carbonate equivalent by the Piper rapid titration method (Hesse, 1971), organic carbon by the Kurmies me-

Table 1. Characteristics of the soils used in the investigation.

\begin{tabular}{|c|c|c|c|c|c|c|c|c|c|c|}
\hline $\begin{array}{l}\text { Soil } \\
\text { No }\end{array}$ & $\begin{array}{l}\text { Sand } \\
(\%)\end{array}$ & $\begin{array}{l}\text { Silt } \\
(\%)\end{array}$ & $\begin{array}{l}\text { Clay } \\
(\%)\end{array}$ & $\begin{array}{l}\text { Textural } \\
\text { gradel }^{1}\end{array}$ & $\begin{array}{l}\mathrm{CaCO}_{3} \\
\text { equiv. } \\
\text { (\%) }\end{array}$ & $\begin{array}{l}\text { Organic } \\
\text { carbon } \\
(\%)\end{array}$ & $\begin{array}{l}\text { Total } \\
\text { nitrogen } \\
(\%)\end{array}$ & $\mathrm{pH}$ & $\begin{array}{l}\text { CEC } \\
\text { (meq' } \\
\text { lo0 g) }\end{array}$ & $\begin{array}{l}\text { Urease } \\
\text { activity }^{2}\end{array}$ \\
\hline 1 & 89 & 9 & 2 & S & 0.0 & 0.43 & 0.02 & 4.9 & 2.6 & 247 \\
\hline 2 & 88 & 8 & 4 & LS & 0.0 & 0.22 & 0.02 & 4.3 & 2.1 & 247 \\
\hline 3 & 81 & 14 & 5 & LS & 0.0 & 0.41 & 0.05 & 5.9 & 2.6 & 238 \\
\hline 4 & 63 & 28 & 9 & SL & 1.0 & 0.45 & 0.05 & 5.8 & 9.7 & 258 \\
\hline 5 & 49 & 42 & 9 & $\mathrm{~L}$ & 4.0 & 0.79 & 0.07 & 7.4 & 9.7 & 250 \\
\hline 6 & 30 & 58 & 12 & SiL & 6.2 & 0.87 & 0.08 & 7.4 & 34.1 & 269 \\
\hline 7 & 59 & 16 & 25 & SCL & 0.0 & 0.57 & 0.04 & 5.1 & 16.5 & 268 \\
\hline 8 & 35 & 29 & 36 & $\mathrm{CL}$ & 0.0 & 1.69 & 0.07 & 7.3 & 29.6 & 268 \\
\hline
\end{tabular}

$\mathrm{S}=$ sand, $\mathrm{LS}=$ loamy sand, $\mathrm{SL}=$ sandy loam, $\mathrm{L}=$ loam, $\mathrm{SiL}=$ silty loam, $\mathrm{SCL}=$ sandy clay loam, $\mathrm{CL}=$ clay loam.

${ }^{2} \mu \mathrm{g}$ of urea hydrolysed $\mathrm{g}^{-1}$ of soil $\mathrm{h}^{-1}\left(37^{\circ} \mathrm{C}\right)$. 
thod, total nitrogen by a semi-micro Kjeldahl procedure, $\mathrm{pH}$ by a glass electrode in a $1: 2.5(\mathrm{w} / \mathrm{v})$ suspension of $\mathrm{CaCl}_{2} 0.01 \mathrm{M}, \mathrm{CEC}$ by percolation with ammonium acetate $1 \mathrm{M}$, buffered at $\mathrm{pH} 8.2$ for calcareous soils or at $\mathrm{pH} 7.0$ for noncalcareous soils. Urease activity was determined by the non-buffer method, described by Zantua \& Bremner (1975).

Analyses of $1: 5(\mathrm{w} / \mathrm{v})$ soil-water extracts showed these soils to be almost free of water-soluble portions of $\mathrm{Fe}, \mathrm{Cu}$, and $\mathrm{Zn}$. It should be pointed out that, in general, heavy metal activities in soils are not characterized by their water-soluble concentrations. These analyses, however, were performed in order to determine the exact initial concentrations of these metallic ions. In all experiments $\mathrm{Fe}, \mathrm{Cu}$, or $\mathrm{Zn}$ was applied as the sulphate of the bivalent cation.

To study the effects of these ions on urea decomposition in soil, samples of air-dried soil, containing $5 \mathrm{~g}$ of oven-dry material, were placed in $100-\mathrm{ml}$ glass bottles. Sufficient water was added to bring the total volume of water in each sample to $2 \mathrm{ml}$. The samples were then treated with $1 \mathrm{ml}$ of water containing 2 $\mathrm{mg}$ of urea alone or $2 \mathrm{mg}$ of urea plus either 25,50 , or $100 \mu \mathrm{g}$ of the metal tested. The bottles were stoppered and incubated at $25^{\circ} \mathrm{C}$. After 24 or 48 hours, the soils of duplicate bottles from each treatment were extracted with $50 \mathrm{ml}$ of a $2 \mathrm{M}$ $\mathrm{KCl}$ solution, containing $250 \mu \mathrm{g}$ of phenylmercuric acetate (PMA, an effective urease inhibitor), and the extracts were analysed for urea by the colorimetric procedure described by Douglas \& Bremner (1970).

A study of the effects of these metallic ions on the production of urease by soil micro-organisms was performed in only two soils (Nos 3 and 5 from Table 1) where samples of air-dried soil, containing $5 \mathrm{~g}$ of oven-dry material, were placed in $100-\mathrm{ml}$ glass bottles and treated with $1 \mathrm{ml}$ of water containing either $10 \mathrm{mg}$ of glucose alone or $10 \mathrm{mg}$ of glucose plus $100 \mu \mathrm{g}$ of metal. Water was added to bring the total volume to $2 \mathrm{ml}$ per sample. The bottles were stoppered and incubated at $30^{\circ} \mathrm{C}$. After 24 and 48 hours duplicate bottles were removed from the incubator, and urease activity in the incubated soil samples was assayed by the non-buffer method described by Zantua \& Bremner (1975).

To investigate the effects of ferrous, cupric, and zinc ions on the volatilization of ammonia from urea-treated soil, portions of air-dried soil, containing $10 \mathrm{~g}$ of oven-dry material of soil No 3 (Table 1) were placed in 250-ml French square bottles and treated with $2 \mathrm{ml}$ of water containing either $10 \mathrm{mg}$ of urea- $\mathrm{N}$ alone or $10 \mathrm{mg}$ of urea-N plus $200 \mu \mathrm{g}$ of metal. Water was added to bring the total volume to $3 \mathrm{ml}$ per sample. The bottles were fitted with an aeration device having an acid trap for absorption of ammonia evolved during incubation which was maintained at $20^{\circ} \mathrm{C}$ (Bremner \& Douglas, 197lb). After 14 days duplicate bottles were removed from the incubator, and the ammonium in the acid traps was determined (Bremner \& Edwards, 1965). The incubated soil was analysed for urea, soluble + exchangeable ammonium, and nitrate + nitrite (Douglas $\&$ 
Bremner, 1970; Bremner \& Keeney, 1966).

Most experiments and analyses were performed in triplicate. The results reported in this paper are the mean values.

\section{Results and discussion}

\section{Urease activity in the different soils}

In comparison with data presented by Zantua \& Bremner (1975), urease activity is very high in all soils (Table 1). Probably the buffering capacities of the soils are not sufficient to prevent high $\mathrm{pH}$ values of the soil suspensions after urea decomposition. It is known that urease activity can be increased under alkaline conditions. (Bremner \& Mulvaney, 1978). The small differences in urease activity in the different soil samples (Table 1) suggest that the $\mathrm{pH}$ had reached such a high value that urease was inactivated within the 5-hour incubation period. Combination of different rates of urea hydrolysis and different moments of urease inactivation can yield values for urease activity which do not deviate significantly.

\section{Retardation of urea hydrolvsis}

The results of the effects of ferrous, cupric, and zinc ions on urea hydrolysis in the eight experimental soils are presented in Table 2. It is striking that in all soils the amounts of urea hydrolysed were very high and only slightly correlated with organic matter content and texture. On the average, 77 and $85 \%$ of the added urea was already hydrolysed after 24 and 48 hours, respectively. These observations suggest that the soil-dependent rate of urea decomposition can only be detected during the first hours. In course of time, differences in the amounts of urea hydrolysed are thus eliminated. For that reason, inhibitory effects as reported in Table 2 are probably somewhat disguised. In most cases, the lower conconcentrations of metallic ions had a very slight or even no effect on retardation of urea hydrolysis. The effectiveness of these ions was obvious only when applied at a concentration of $20 \mu \mathrm{g} \mathrm{g}^{-1}$ of soil with variations in the effect of each ion from one soil to another and in the effect of different ions in each special soil. The results indicate that the inhibitory effect of metallic ions is most pronounced in light-textured soils and smaller in the heavier ones. This behaviour may be due to adsorption of these ions in the heavy-textured soils and may, thus, suggest that their potential values as urease inhibitors are greatest in light-textured soils.

Results obtained by many investigators (Bahadur \& Chandra, 1962; Daif \& Badr El-Din, 1979; Hughes et al., 1969; Shaw, 1954; Shaw \& Raval, 1961; Toren \& Burger, 1968) have shown that urease isolated from plants or micro-organisms is inactivated by very small amounts of $\mathrm{Fe}^{2+}, \mathrm{Cu}^{2+}, \mathrm{Zn}^{2+}$, and other heavy 
Table 2. Effect of ferrous, cupric, and zinc ions on urea hydrolysis ( $\mu \mathrm{g}$ hydrolysed $\mathrm{g}^{-1}$ of soil, $25^{\circ} \mathrm{C}$ ) in soils during 24 and 48 hours.

\begin{tabular}{|c|c|c|c|c|c|c|c|c|}
\hline $\begin{array}{l}\text { Metallic } \\
\text { ion! }\end{array}$ & $\begin{array}{l}\text { Soil } \\
1\end{array}$ & $\begin{array}{l}\text { Soil } \\
2\end{array}$ & $\begin{array}{l}\text { Soil } \\
3\end{array}$ & $\begin{array}{l}\text { Soil } \\
4\end{array}$ & $\begin{array}{l}\text { Soil } \\
5\end{array}$ & $\begin{array}{l}\text { Soil } \\
6\end{array}$ & $\begin{array}{l}\text { Soil } \\
7\end{array}$ & $\begin{array}{l}\text { Soil } \\
8\end{array}$ \\
\hline \multicolumn{9}{|c|}{24 hours after incubation } \\
\hline None & 252 & 284 & 274 & 286 & 284 & 349 & 364 & 379 \\
\hline $\mathrm{Fe}(5 \mu \mathrm{g})$ & 251 & 280 & 263 & 283 & 280 & 348 & .353 & 372 \\
\hline $\mathrm{Fe}(10 \mu \mathrm{g})$ & 250 & 280 & 262 & 281 & 280 & 348 & 347 & 369 \\
\hline $\mathrm{Fe}(20 \mu \mathrm{g})$ & 218 & 228 & 239 & 268 & 258 & 325 & $33 I$ & 349 \\
\hline $\mathrm{Cu}(5 \mu \mathrm{g})$ & 251 & 278 & 272 & 276 & 278 & 346 & 339 & 371 \\
\hline $\mathrm{Cu}(10 \mu \mathrm{g})$ & 247 & 265 & 268 & 275 & 265 & 335 & 335 & 371 \\
\hline $\mathrm{Cu}(20 \mu \mathrm{g})$ & 213 & 220 & 234 & 258 & 253 & 318 & 315 & 347 \\
\hline $\mathrm{Zn}(5 \mu \mathrm{g})$ & 246 & 273 & 262 & 280 & 273 & 341 & 343 & 365 \\
\hline $\mathrm{Zn}(10 \mu \mathrm{g})$ & 244 & 272 & 259 & 280 & 272 & 339 & $33 \mathrm{I}$ & 364 \\
\hline $\mathrm{Zn}(20 \mu \mathrm{g})$ & 220 & 232 & 235 & 258 & 255 & 326 & 316 & 352 \\
\hline \multicolumn{9}{|c|}{48 hours after incubation } \\
\hline None & 269 & 323 & 278 & 326 & 323 & 398 & 399 & 400 \\
\hline $\mathrm{Fe}(5 \mu \mathrm{g})$ & 267 & 316 & 277 & 326 & 316 & 396 & 398 & 399 \\
\hline $\mathrm{Fe}(10 \mu \mathrm{g})$ & 267 & 325 & 271 & 323 & 315 & 396 & 395 & 399 \\
\hline $\mathrm{Fe}(20 \mu \mathrm{g})$ & 243 & 267 & 271 & 309 & 300 & 392 & 392 & 394 \\
\hline $\mathrm{Cu}(5 \mu \mathrm{g})$ & 269 & 313 & 273 & 323 & 313 & 395 & 399 & 399 \\
\hline $\mathrm{Cu}(10 \mu \mathrm{g})$ & 264 & 313 & 266 & 317 & 313 & 392 & 388 & 399 \\
\hline $\mathrm{Cu}(20 \mu \mathrm{g})$ & 235 & 246 & 254 & 293 & 292 & 387 & 387 & 394 \\
\hline $\operatorname{Zn}(5 \mu \mathrm{g})$ & 265 & 314 & 269 & 323 & 314 & 398 & 397 & 400 \\
\hline $\mathrm{Zn}(10 \mu \mathrm{g})$ & 264 & 311 & 265 & 322 & 311 & 398 & 394 & 399 \\
\hline $\mathrm{Zn}(20 \mu \mathrm{g})$ & 245 & 262 & 265 & 303 & 299 & 393 & 379 & 396 \\
\hline
\end{tabular}

1 Amount of metal added per gram of soil is indicated in parentheses.

metals. Data obtained by Bremner \& Douglas (197la) and Daif \& Badr El-Din (1979) and the results of the present work indicate that the amounts of heavy metal ions needed to cause substantial inhibition of soil urease were much larger than the amounts needed for equivalent inhibition of pure jack bean or soya bean urease. Long-term application of such ions at high concentrations may be, however, undesirable because of their potential phytotoxic properties, especially on light-textured soils.

The inhibitory effects of $20 \mu \mathrm{g} \mathrm{g}^{-1}$ of soil of either ferrous, cupric, or zinc ions were usually comparable to, and sometimes greater than those reported by Bremner \& Douglas (1971a), who used concentrations of $50 \mu \mathrm{g} \mathrm{g}^{-1}$ of soil. This could suggest that the degree of contact of the metallic ion with urea is one of the factors determining the effectiveness of the inhibition. If this is true, it may be possible to use these metallic ions at much lower concentrations. At this moment the authors are aiming at finding a reliable method to evaluate such metals, especially for the way of mixing them manufacturally with urea. 
Table 3. Effect of ferrous, cupric, and zinc ions on urease activity in two soils treated with glucose.'

\begin{tabular}{|c|c|c|c|c|}
\hline \multirow{2}{*}{$\begin{array}{l}\text { Soil } \\
\text { No }\end{array}$} & \multirow{2}{*}{$\begin{array}{l}\text { Metallic } \\
\text { ion }\end{array}$} & \multicolumn{3}{|c|}{ Urease activity after...$h$ of incubation at $30^{\circ} \mathrm{C}$} \\
\hline & & 0 & 24 & 48 \\
\hline \multirow[t]{4}{*}{3} & None & $238 \pm 0.9$ & $257 \pm 6.0$ & $260 \pm 4.9$ \\
\hline & $\mathrm{Fe}$ & $238 \pm 1.4$ & $257 \pm 2.6$ & $260 \pm 4.4$ \\
\hline & $\mathrm{Cu}$ & $239 \pm 4.0$ & $257 \pm 4.6$ & $261 \pm 5.7$ \\
\hline & $\mathrm{Zn}$ & $239 \pm 3.4$ & $257 \pm 5.8$ & $261 \pm 6.4$ \\
\hline \multirow[t]{4}{*}{5} & None & $250 \pm 2.1$ & $270 \pm 4.0$ & $272 \pm 5.7$ \\
\hline & $\mathrm{Fe}$ & $249 \pm 5.5$ & $269 \pm 4.7$ & $272 \pm 2.0$ \\
\hline & $\mathrm{Cu}$ & $250 \pm 4.2$ & $269 \pm 6.8$ & $272 \pm 2.2$ \\
\hline & $\mathrm{Zn}$ & $250 \pm 6.9$ & $270 \pm 7.1$ & $273 \pm 2.4$ \\
\hline
\end{tabular}

$12 \mathrm{mg}$ of glucose $\mathrm{g}^{-1}$ of soil with or without $20 \mu \mathrm{g}$ of metal $\mathrm{g}^{-1}$ of soil.

$2 \mu \mathrm{g}$ of urea hydrolysed $\mathrm{g}^{-1}$ of soil $\mathrm{h}^{-1}\left(37^{\circ} \mathrm{C}\right)$.

\section{Microbial production of urease}

To study the effects of the metallic ions on the production of urease by soil micro-organisms, the urease activity in two soils (Nos 3 and 5 from Table 1) was determined after incubation of soils with glucose. This compound was added to stimulate production of urease by soil micro-organisms. The results presented in Table 3 show that urease activity was only slightly stimulated after application of glucose in the control treatments. This suggests that addition of a carbon source to soils, in which inorganic nitrogen is practically absent, is not sufficient to stimulate bacterial growth substantially within 48 hours. Ferrous, cupric, and zinc ions did not affect microbial production of urease, even when applied at a concentration of $20 \mu \mathrm{g} \mathrm{g}^{-1}$ of soil.

From these results and those of the previously described experiment the conclusion seems to be justified that retardation of urea hydrolysis in soils in response to addition of ferrous, cupric, or zinc ions was not achieved by controlling the biosynthesis of urease, but by inhibiting the activity of (the extracellular fraction of this enzyme present in the soil before treatment.

It is generally accepted that critical concentrations of heavy metals such as iron, copper, and zinc in the leaves, associated with nutrient deficiency symptoms in higher plants, are valid almost universally, regardless of climatic conditions or soil type, as long as the sampling techniques and analytical methods are comparable throughout. On the other hand, the values associated with phytotoxicity will vary over a rather wide range, since reduction in growth and appearance of symptoms will vary strongly with light intensity, temperature, moisture stress, salt composition, textural grade, acidity and organic matter content of the soil. Since the highest concentration of metallic ions used in our experiments $(20 \mu \mathrm{g}$ $\mathrm{g}^{-1}$ of soil) did not affect the activity of ureolytic micro-organisms, it can be postulated that such a concentration probably does not injure plants but, perhaps, 
may even promote their growth. This postulation is based on the widely accepted theorem that plants are more tolerant than micro-organisms. We think, however, that more knowledge is necessary about the effects of long-term application of these metals on plant growth before leaving our earlier mentioned statement that application of such ions at these concentrations is undesirable in principle.

\section{Ammonia volatilization and nitrification}

Table 4 shows the results of a comparison of the effects of metallic-ion applications ( $20 \mu \mathrm{g} \mathrm{g}^{-1}$ of soil) on the recovery of urea- $\mathrm{N}$ as urea. soluble + exchangeable ammonium, ammonia, and nitrate + nitrite, when a loamy sand (soil No 3 from Table 1), treated with urea, was incubated at $20^{\circ} \mathrm{C}$ for 14 days.

It can be seen that, compared with zinc and ferrous ions, the cupric ion markedly retarded urea hydrolysis and reduced volatilization of ammonia, while more nitrate + nitrite accumulated in the soil. The superiority of the Cu treatment in retarding urea decomposition, presumed to be due to the reaction of cupric ions with the amide groups of urea and/or urease, can be explained by postulating the formation of organo-metal complexes which are more stable than those formed in case of either ferrous of zinc treatments. These relatively stable complexes may be considered as the limiting factor which restricts the urea hydrolysis rate. This assumption is supported by the values of residual urea as represented in Table 4.

It is well known that ammonium ions in solution may be adsorbed by soil colloids, or transformed to nitrate or ammonia (Chu \& Knowles, 1966). In addition, equilibria exist between adsorbed ammonium, ammonium in solution and free ammonia. Consequently, any increase in the production of ammonium ions will give rise to the evolution of gaseous ammonia. In this connection, Ernst \& Massey (1960) reported that free ammonia is always produced following the formation of ammonium carbonate in the course of urea hydrolysis in the soil. The very high ammonium concentrations prevented the onset of the nitrification process in the zinc and ferrous treatments. The deviating behaviour of the cu-

Table 4. Effect of ferrous, cupric, and zinc ions on transformations of urea to free ammonia, soluble + exchangeable ammonium, and nitrate + nitrite after incubation of urea treated soil No 3 from Table 1) for 14 days at $20^{\circ} \mathrm{C}$.

\begin{tabular}{|c|c|c|c|c|c|}
\hline \multirow{2}{*}{$\begin{array}{l}\text { Metallic } \\
\text { ion per } \\
\mathrm{g} \text { of soil }\end{array}$} & \multicolumn{5}{|c|}{ Recovery of urea-N (\%) } \\
\hline & as urea & as $\mathrm{NH}_{3}$ & as $\mathrm{NH}_{4}^{+}$ & as $\mathrm{NO}_{3}^{-}+\mathrm{NO}_{2}^{-}$ & total \\
\hline None & $16.0 \pm 0.5$ & $18.8 \pm 0.9$ & $62.0 \pm 1.3$ & $1.0 \pm 1.0$ & 97.8 \\
\hline $\mathrm{Fe} 20 \mu \mathrm{g}$ & $18.3 \pm 0.8$ & $19.0 \pm 1.2$ & $60.0 \pm 1.5$ & $1.0 \pm 0.8$ & 98.3 \\
\hline $\mathrm{Cu} 20 \mu \mathrm{g}$ & $30.5 \pm 2.8$ & $9.2 \pm 1.1$ & $42.1 \pm 1.7$ & $17.0 \pm 1.0$ & 98.9 \\
\hline $\mathrm{Zn} 20 \mu \mathrm{g}$ & $20.2 \pm 0.9$ & $16.0 \pm 1.0$ & $60.8 \pm 7.7$ & $1.0 \pm 1.1$ & 98.0 \\
\hline
\end{tabular}


pric ion with respect to ammonia evolution can be due to the formation of $\mathrm{Cu}$ $\mathrm{NH}_{3}$ complexes and hence to suppression of substrate inhibition in the nitrification reactions. As copper is known as an essential cofactor in nitrifying enzymes, it is not excluded that addition of copper stimulates the formation of nitrite by Nitrosomonas species, despite of the high ammonium concentration.

\section{Acknowledgements}

We like to thank Dr M. E. Ibrahim and Mr Th. M. Lexmond for their valuable comments on the manuscript. The first author wishes to express his sincere gratitude to Dr L. P. van Reeuwijk of the International Soil Museum for encouraging discussions and hospitality during his stay in the Netherlands.

\section{References}

Anderson, J. R., 1962, Urease activity, ammonia volatilization and related microbiological aspects in some South African soils. Proc. 36th Congr. S. Afr. Engng Technol. Ass.: 97-105.

Anderson, J. R., 1969. Fertilizing process and composition. British Patent No 1, 142,245.

Bahadur, K. \& V. Chandra, 1962. A study of the inhibitory influence of $\mathrm{Ag}^{+}, \mathrm{Au}^{3+}$, and $\mathrm{Cu}^{2+}$ ions on the decomposition of urea by soybean (Glycine soja) urease. Proc. Natl. Acad. Sci. India A32: 72-82.

Besekau, E., G. Harzfeld, R. Kuemmel, W. Matzel, D. Muehlenbruch \& G. Thomas, 1974. Nitrogen-containing fertilizer. East German Patent No 108.730.

Bremner, J. M. \& L. A. Douglas, 1971a. Inhibition of urease activity in soils. Soil Biol. Biochem. 3: 297-307.

,Bremner, J. M. \& L. A. Douglas, 1971b. Decomposition of urea phosphate in soils. Soil Sci. Soc. Am. Proc. 35: 575-578.

Bremner, J. M. \& A. P. Edwards, 1965. Determination and isotope-ratio analysis of different forms of nitrogen in soils. 1. Apparatus and procedure for distillation and determination of ammonium. Soil Sci. Soc. Am. Proc. 29: 504-507.

Bremner, J. M.\& D. R. Keeney, 1966. Determination and isotope-ratio analysis of different forms of nitrogen in soils. 3. Exchangeable ammonium, nitrate, and nitrite by extraction-distillation methods. Soil Sci. Soc. Am. Proc. 30: 577-582.

Bremner, J. M. \& R. L. Mulvaney, 1978. Urease activity in soils. In: R. G. Burns (Ed.), Soil enzymes. Academic Press, London, etc., pp. 149-196.

Chu, J. P. H. \& R. Knowles, 1966. Mineralization and immobilization of nitrogen in bacterial cells and in certain soil organic fractions. Soil Sci. Soc. Am. Proc. 30: 210-213.

Daif, M. A. \& M. Badr El-Din, 1979. Studies on urea hydrolysis. 2. Effect of some heavy metals on urease activity. Beitr. trop. Landw. Veterinärmed. 17: 261-266.

Douglas, L. A. \& J. M. Bremner, 1970. Extraction and colorimetric determination of urea in soils. Soil Sci. Soc. Am. Proc. 34: 859-862.

Ernst, J. W. \& H. F. Massey, 1960. The effects of several factors on volatilization of ammonia formed from urea in the soil. Soil Sci. Soc. Am. Proc. 24: 87-90.

Geissler, P. R., K. Sor \& T. M. Rosenblatt, 1970. Urease inhibitors. US Patent Office 3,523,018.

Hesse, P. R., 1971. A textbook of soil chemical analysis. John Murray Publishers, London.

Hughes, R. B., S. A. Katz \& S. E. Stubbins, 1969. Inhibition of urease by metal ions. Enzymologia 36: 332-334.

Hyson, A. M., 1963. Fertilizer composition comprising urea and dithiocarbamates. US Patent Office $3,073,694$. 
Peterson, A. F. \& C. R. Jr. Walter, 1970. Regulation of urea hydrolysis in soil. US Patent Office $3,547,614$.

Shaw, W. H. R., 1954. The inhibition of urease by various metal ions. J. Am. chem. Soc. 76: 21602163

Shaw, W. H. R. \& D. N. Raval. 1961. The inhibition of urease by metal ions at pH 8.9. J. Am. chem. Soc. 83: 3184-3187.

Sor, K. M., 1968. Fertilizer composition consisting of urea, a urease inhibitor, and a hydrocarbon binder. US Patent Office 3.388.989.

Sor, K. M., 1969. Inhibition of urea hydrolysis in fertilizers. British Patent No 1,157,400.

Sor, K. M., J. A. Pelissier \& R. Jr. Latham, 1968. Urea fertilizer with slow ammonia release. French Patent No 1.519.208.

Sor, K. M., J. A. Pelissier \& R. Jr. Latham, 1971. Urease inhibited urea-containing compositions. US Patent Office 3,565,599.

Tomlinson, “. E., 1967. Controlling urea hydrolysis in soils. British Patent No 1,094,802.

Toren, E. C.\& F. J. Burger, 1968. Trace determination of metal ion inhibitors of the urea-urease system by a pH-stat kinetic method. Microchim. Acta 5: 1049-1058.

Zantua, M. I. \& J. M. Bremner, 1975. Comparison of methods of assaying urease activity in soils. Soil Biol. Biochem. 7: 291-295. 